\title{
Study on the quality of wines produced from 'Syrah' and 'Tempranillo' cultivars planted in two microregions in Southern Bulgaria
}

\author{
Lyudmil Angelov, Boyan Stalev \\ Department of Viticulture \\ Faculty of Viticulture and Horticulture, Agricultural University in Plovdiv \\ Mendeleev Street 12, 4000, Plovdiv, Bulgaria \\ e-mail: vitis.vin_29@abv.bg
}

\begin{abstract}
In the period 2006-2008 a comparative study was carried out on the 'Tempranillo', 'Syrah 99' and 'Syrah 100' cultivars, grown in two microregions in Southern Bulgaria - Brestnik and Pesnopoy. The soils in the region of Pesnopoy are of a better mechanical and chemical composition, which preconditions the formation of relatively high yields of good quality grapes. The 'Tempranillo' cultivar was highly productive in both microregions, however the quality of the wines was lower, compared to the 'Syrah' cultivar. They were poorer both in the content of extract and in fruit aroma. 'Syrah 99' from Brestnik and 'Syrah 100' clones from Pesnopoy do not differ significantly in productivity, but the wines of 'Syrah 100' from the Pesnopoy region were more intense in colour and their aroma was strong, full-bodied and lasting with dominating floral (violet) and forest fruit nuances. Tasting results showed high scores, which is evidence that the young wines have potential and contain the ingredients and components necessary to develop further into top quality red wines.
\end{abstract}

Key words: aroma, grape vinification, regional distribution, wine quality

\section{INTRODUCTION}

It is known that the terroir (the combination of soil, subsoil and climatic conditions) has a direct effect on the quantity and quality of the grapes and on the wines produced (Crespy 1992, Galet 1993, Raynier 2001, Penkov 2005). That is why the microregional distribution of grapevine cultivars should be preceded by in-depth studies of the mechanical and chemical soil composition, orography, exposure of the area, as well as on the climatic conditions formed over a longer period of time of at least 30-50 years (Branas 1974, Babrikov et al. 2000, Katerov et al. 2005).

The 'Syrah' and 'Tempranillo' red wine varieties are of interest to the wine community. They are comparatively new cultivars for Bulgaria. The first vineyards were established in the Training and
Experimental Fields of the Agricultural University in Plovdiv in 2001 and in Darobas in the village of Pesnopoy, Karlovo municipality, in 2002.

The aim of the present study was to establish the manifestation of the biological potential of both cultivars, known for their valuable economic qualities realised in the conditions of France (Galet 1993, Boidron et al. 1995), under comparatively similar climatic conditions but different soil characteristics in Southern Bulgaria.

\section{MATERIAL AND METHODS}

The studies were carried out using two cultivars. The first one is 'Syrah' clones 'Syrah 99' and 'Syrah 100', which were developed in 1971 in the region of Drome, France by the National Service for the Improvement of Viticulture. In recent years 
Table 1. Soil and climatic characteristics

\begin{tabular}{|c|c|c|c|c|c|c|c|c|c|c|}
\hline \multirow[b]{2}{*}{$\begin{array}{l}\text { Region, } \\
\text { locality }\end{array}$} & \multirow{2}{*}{$\begin{array}{l}\text { Height } \\
\text { above } \\
\text { sea level } \\
\text { (m) }\end{array}$} & \multicolumn{5}{|c|}{ Soil } & \multicolumn{4}{|c|}{ Climatic characteristics } \\
\hline & & Soil type & $\begin{array}{l}\text { Supply of } \\
\text { major nutrient } \\
\text { substances }\end{array}$ & $\begin{array}{l}\text { Humus } \\
\text { content } \\
(\%)\end{array}$ & $\mathrm{pH}$ & $\begin{array}{l}\text { Active } \\
\mathrm{Ca} \\
(\%)\end{array}$ & $\begin{array}{l}\sum \mathrm{t} \\
\left({ }^{\circ} \mathrm{C}\right)\end{array}$ & $\begin{array}{l}\text { Temperature } \\
\text { in the hottest } \\
\text { month }\left({ }^{\circ} \mathrm{C}\right)\end{array}$ & $\begin{array}{c}\sum \text { of } \\
\text { precipitation } \\
(\mathrm{mm})\end{array}$ & $\begin{array}{c}\text { Frost-free } \\
\text { period } \\
\text { in days }\end{array}$ \\
\hline $\begin{array}{l}\text { Brestnik } \\
\text { village, } \\
\text { Rhodope } \\
\text { Municipality }\end{array}$ & 250 & $\begin{array}{l}\text { Delluvial } \\
\text { and } \\
\text { prolluvial } \\
\text { deposits }\end{array}$ & good & 2.01 & 7.2 & 0.8 & 3925 & 23.00 & 624 & 210 \\
\hline $\begin{array}{l}\text { Pesnopoy } \\
\text { village, } \\
\text { Karlovo } \\
\text { Municipality }\end{array}$ & 282 & $\begin{array}{l}\text { Diluvial } \\
\text { deposits }\end{array}$ & good & 2.20 & 6.8 & 3.0 & 3812 & 23.01 & 650 & 213 \\
\hline
\end{tabular}

they have been introduced in almost all European countries. The second was the 'Tempranillo' cultivar from the Rioja valley, Spain. It is grown in Spain, Italy, France and other countries. Both varieties are grafted on 'Berlandieri' $\times$ 'Riparia S04' rootstock. The vineyards were seven and eight years old, respectively. The vines were trained to a trunk unilateral cordon system at the Agricultural University and to a trunk bilateral cordon system in Pesnopoy village, with the trunk height at 0.80 $\mathrm{cm}$. The number of normally developed vines per ha was 4,100 . During pruning the vines were loaded with 6-8 spurs with two winter buds on each, i.e. 16-18 winter buds in total. Soil analyses were made following the methods described in the Manual in Agrochemistry (Tomov et al. 1999) and in the Manual for seminars in soil science (Totev et al. 1999). Climatic characteristics were developed based on data from the Climatic Reference Book of the Republic of Bulgaria. Microvinification was conducted in a flow diagram for red table wines. All of the varieties were sampled from $50 \mathrm{~kg}$ of grapes and crushed shell with small hand roll crushers. Fermentation was conducted in a floating hat in the same temperature from 25 to $28^{\circ} \mathrm{C}$. Liquid and solid phase homogenisation was done by hand, dipping the cap twice a day. Wines indicators were investigated by the methods described in the Guide for practical exercises in winemaking (Kantarev 1973). Table 1 presents the data about the most important soil and climatic characteristics of the terroir.

Climatically, both regions belong to a transitional continental climatic zone. The temperature regime is characterised by relatively hot summers and mild winters (Tab. 1). The mean annual air temperature for the village of Brestnik is $12.6^{\circ} \mathrm{C}$ and $12.8^{\circ} \mathrm{C}$ for Pesnopoy (the town of Banya). The mean monthly air temperatures in the winter and summer months are relatively consistent. The lowest minimum temperatures have been measured in January.
Minimum temperatures in the interval from $-15.1{ }^{\circ} \mathrm{C}$ to $-20.0^{\circ} \mathrm{C}$ and $-25.0^{\circ} \mathrm{C}$, which are dangerous for vine plants, have been rarely recorded - not more than once in a 10-15-year period. The frost-free periods last for 210 and 213 days for the region of Brestnik and Pesnopoy, respectively. The temperature sum for both regions is above $3,800^{\circ} \mathrm{C}$ and it is absolutely enough for the grapes to ripen, even for the late cultivars. This conclusion is also confirmed by the data about the temperature measured in the hottest month of July.

The precipitation sum in both microregions is within $95 \%$ of the probability level. The soils are clayey in mechanical composition, the clay being $26-40 \%$. The texture coefficient of soil is above 1.01.2-1.5. It has good water and physical properties - good water permeability combined with a good water-retaining capacity. The humus reserves in the surface soil layer are high and in the whole onemeter soil layer - medium to high. Soil response is slightly alkaline. Salt content above the ultimate concentrations for normally developed soils was not detected. The content of active calcium was very low (Tab. 1). The amount of absorbable ammonium nitrate, easily absorbable phosphorus and potassium was good.

A brief soil and climate analysis of both microregions showed that they were very suitable for growing red wine cultivars for the production of top quality wines.

\section{RESULTS AND DISCUSSION}

\section{Brief botanical, agrobiological and technological characteristics}

\section{'Tempranillo' cultivar}

Botanical description. The developed leaf is large and five-lobed. The upper leaf blade surface is almost glabrous and smooth while the lower one is prostrate and pubescent. The upper sinuses are 
deep, closed with a circular aperture while the lower ones are open, lyre-shaped with a wide mouth. The fruit cluster was medium-large $(17.3-12.1 \mathrm{~cm})$, winged (usually with two wings), conical, and medium-compact (Fig. 1). The berry was medium large (12.4-13.4 mm) and spherical. The skin was thick, tough, blue-black in colour, and abundantly wax-coated. The mean weight of the fruit cluster in Brestnik was $266 \mathrm{~g}$ and $270 \mathrm{~g}$ in Pesnopoy. The weight of 100 berries was $180.3 \mathrm{~g}$ and $176.0 \mathrm{~g}$, respectively (Tab. 2).

Agrobiological characteristics. The cultivar has very good fertility. The average number of fruit clusters per cane was 1.12 , with 1.53 per fruiting cane. The percentage of developed buds was 85.44 , with $72.36 \%$ of fruiting canes (Tab. 3).

Technological characteristics. The grapes ripened in the second week of September. They accumulated $22.9 \%$ sugars and $6.6 \mathrm{~g}$ per $\mathrm{dm}^{3}$ titrable acids in Brestnik and $23.60 \%$ sugars and $6.90 \mathrm{~g}$ per $\mathrm{dm}^{3}$ acids in Pesnopoy (Tab. 2). The

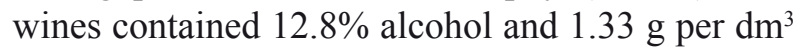
residual sugar. The total extract was $24.93 \mathrm{~g}$ per $\mathrm{dm}^{3}$ and $23.60 \mathrm{~g}$ per $\mathrm{dm}^{3}$ of the sugar-free extract for the region of Brestnik and 13.2\% and $1.95 \mathrm{~g}$ per

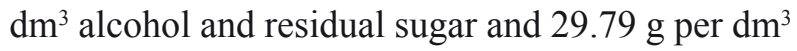
and $27.84 \mathrm{~g}$ per $\mathrm{dm}^{3}$ total and sugar-free extract for the region of Pesnopoy, respectively (Tab. 4).

The wines were distinguished by a lively and sparklingly ruby red colour and less expressed fruitiness in the region of Brestnik compared to those from Pesnopoy. The taste is full-bodied, harmonious, and more or less neutral. The specific fruity character of the cultivar is lacking. The finish was lasting, pleasant, clear, and winy. The tasting score of the 'Tempranillo' wine from Brestnik region was 75.70 and 76.40 from the region of Pesnopoy (Tab. 4).

\section{'Syrah' cultivars (clones 'Syrah 99' and 'Syrah 100')}

Botanical description. The developed leaf is large and five-lobed. The upper leaf blade surface is reticular, wrinkled, with gentle web-like filaments, while the lower one is slightly glaucous. The upper sinuses are medium deep and closed with an oval aperture, while the lower ones are open and lyreshaped with a wide mouth. The fruit cluster was medium-large (15.9-8.8 cm), conical, and mediumcompact in both clones of the cultivar (Fig. 2). The berry was medium large (13.5-11.9 mm) and spherical. The skin was thick, tough, blueblack in colour, and abundantly wax-coated. The mean weight of the fruit cluster of 'Syrah 99' was $148 \mathrm{~g}$ and $145 \mathrm{~g}$ for 'Syrah 100'. The weight of 100 berries was $152 \mathrm{~g}$ and $150 \mathrm{~g}$, respectively (Tab. 2).

Agrobiological characteristics. The cultivar demonstrates good fertility. The average number of fruit clusters per cane was 1.33 and 1.71 per fruiting cane. The percentage of the developed buds was 78.07, with $77.33 \%$ fruiting canes (Tab. 3).

Technological characteristics. The grapes ripened in the middle of September. 'Syrah 99' grapes accumulated $23.40 \%$ sugars and $6.8 \mathrm{~g} \mathrm{per} \mathrm{dm}^{3}$ titrable acids and 'Syrah 100' grapes accumulated $24.10 \%$ sugars and $6.45 \mathrm{~g}$ per $\mathrm{dm}^{3}$ titrable acids, respectively (Tab. 2). The wines contained $12.8 \%$ alcohol and $1.71 \mathrm{~g}$ per $\mathrm{dm}^{3}$ residual sugar. The total

Table 2. Agrobiological and technological characteristics for the period 2006-2008

\begin{tabular}{lccccccc}
\hline Cultivar & Microregion & $\begin{array}{c}\text { Number of } \\
\text { clusters per } \\
\text { cane }\end{array}$ & $\begin{array}{c}\text { Mean } \\
\text { weight of } \\
\text { the cluster } \\
(\mathrm{g})\end{array}$ & $\begin{array}{c}\text { Mean } \\
\text { weight of } \\
100 \text { berries } \\
(\mathrm{g})\end{array}$ & $\begin{array}{c}\text { Yield per } \\
\text { hectare } \\
(\mathrm{t})\end{array}$ & $\begin{array}{c}\text { Sugars } \\
(\%)\end{array}$ & $\begin{array}{c}\text { Titrable } \\
\text { acids } \\
(\mathrm{g} \mathrm{dm})\end{array}$ \\
\hline 'Tempranillo' & Brestnik & 12.9 & 266 & 180.3 & 14.063 & 22.9 & 6.60 \\
\hline & Pesnopoy & 11.5 & 270 & 176.0 & 12.730 & 23.6 & 6.90 \\
\hline 'Syrah 99' & Brestnik & 12.8 & 148 & 152.0 & 7.749 & 23.4 & 6.80 \\
\hline 'Syrah 100' & Pesnopoy & 14.0 & 145 & 150.0 & 8.323 & 24.1 & 6.45 \\
\hline
\end{tabular}

Table 3. Agrobiological characteristics of 'Tempranillo', 'Syrah 99' and 'Syrah 100' cultivars

\begin{tabular}{lcccc}
\hline Cultivar & $\begin{array}{c}\text { Average number } \\
\text { of fruit clusters per } \\
\text { cane }\end{array}$ & $\begin{array}{c}\text { Average number } \\
\text { of fruit clusters per } \\
\text { fruiting cane }\end{array}$ & $\begin{array}{c}\text { Percentage of the } \\
\text { developed buds }\end{array}$ & $\begin{array}{c}\text { Percentage of the fruiting } \\
\text { canes }\end{array}$ \\
\hline 'Tempranillo' & 1.12 & 1.53 & 85.44 & 72.36 \\
\hline $\begin{array}{l}\text { 'Syrah 99' } \\
\text { 'Syrah 100' }\end{array}$ & 1.33 & 1.71 & 78.07 & 77.33 \\
\hline
\end{tabular}




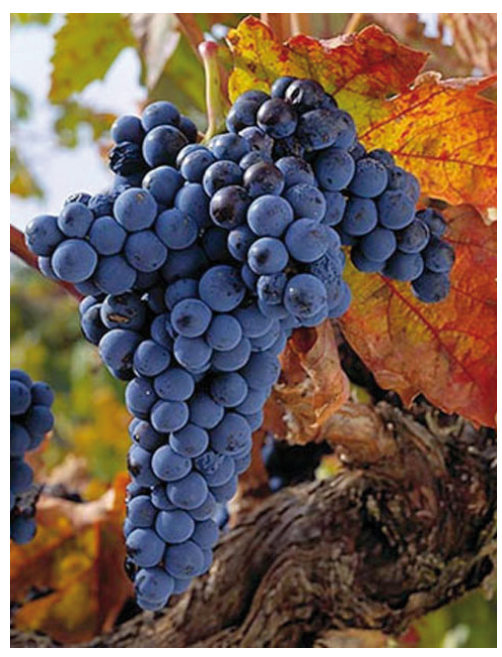

Figure 1. 'Tempranillo' - fruit cluster

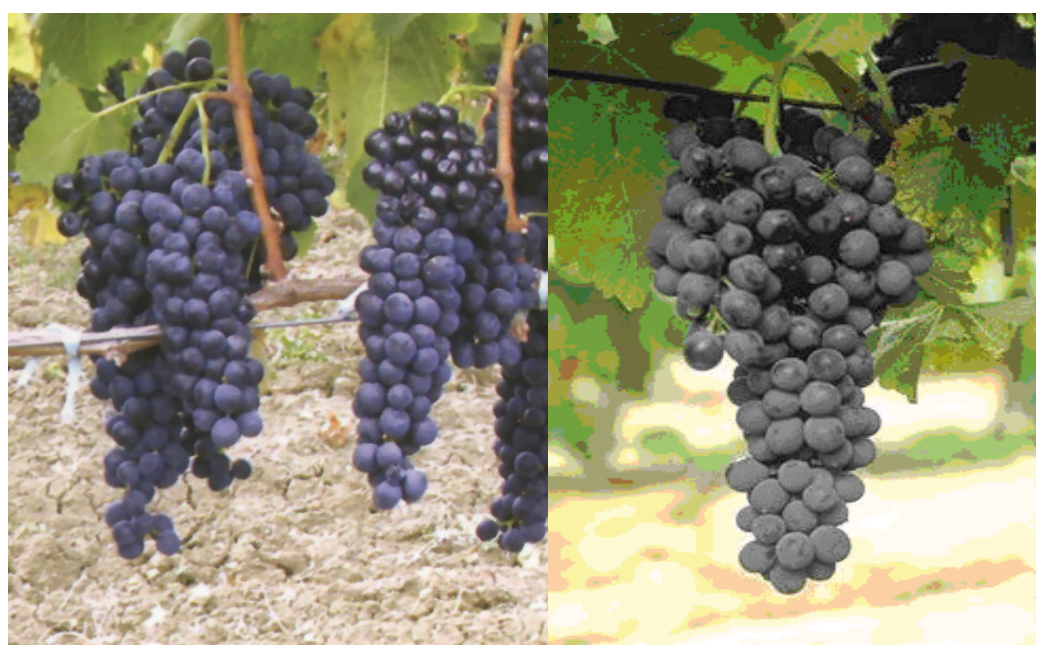

Figure 2. 'Syrah 99' and 'Syrah 100' - fruit clusters extract was $28.77 \mathrm{~g}$ per $\mathrm{dm}^{3}$ and $27.06 \mathrm{~g}$ per $\mathrm{dm}^{3}$ sugar-free extract in 'Syrah 99' and $13.5 \%$ and $1.67 \mathrm{~g}$ per $\mathrm{dm}^{3}$ alcohol and residual sugar and $29.27 \mathrm{~g}$ per $\mathrm{dm}^{3}$ and $27.60 \mathrm{~g}$ per $\mathrm{dm}^{3}$ total and sugarfree extract in 'Syrah 100', respectively (Tab. 4).

The 'Syrah 100' wines are distinguished by their better intensity of colour. The aroma is very powerful, full-bodied and long-lasting. Floral (violet) and forest fruit nuances dominate in it. The 'Syrah 99' wines often tend to have a sweetish touch of dried fruits and chocolate. The taste is full-bodied, well-balanced and harmonious. The wines of both clones are distinguished by a full rounded body with a long-lasting, fine and pleasant aftertaste. The tasting score of 'Syrah 99' wine was 79.80, with 81.50 for 'Syrah 100' (Tab. 4).

\section{CONCLUSIONS}

1. The soils in the region of Pesnopoy are of a better mechanical and chemical composition than in Brestnik, which explains the relatively higher yields of very good quality grapes of the 'Tempranillo' cultivar.

Table 4. Analytical characteristics of the 'Tempranillo', 'Syrah 99' and 'Syrah 100' cultivar wines from two localities, vintage 2007

\begin{tabular}{lcccc}
\hline \multirow{2}{*}{ Characteristic } & \multicolumn{2}{c}{ 'Tempranillo' } & 'Syrah 99' & 'Syrah 100' \\
\cline { 2 - 4 } & Brestnik & Pesnopoy & Brestnik & Pesnopoy \\
\hline Relative density & 0.9929 & 0.9953 & 0.9943 & 0.9949 \\
\hline Alcohol $(\%$ vol.) & 12.8 & 13.2 & 12.8 & 13.5 \\
\hline Total extract $\left(\mathrm{g} \mathrm{dm}^{3}\right)$ & 24.93 & 29.79 & 28.77 & 1.67 \\
\hline Non-prefermented sugars $\left(\mathrm{g} \mathrm{dm}^{3}\right)$ & 1.33 & 1.95 & 1.71 & 27.60 \\
\hline Sugar-free extract $\left(\mathrm{g} \mathrm{dm}^{3}\right)$ & 23.60 & 27.84 & 27.06 & 0.52 \\
\hline Titrable acids $\left(\mathrm{g} \mathrm{dm}^{3}\right)$ & 4.0 & 4.8 & 5.4 & 23.04 \\
\hline Volatile acids $\left(\mathrm{g} \mathrm{dm}^{3}\right)$ & 0.52 & 0.47 & 0.50 & 118.08 \\
\hline Free $\mathrm{SO}_{2}\left(\mathrm{mg} \mathrm{dm}^{3}\right)$ & 25.92 & 30.32 & 20.16 & 5.34 \\
\hline Total $\mathrm{SO}_{2}\left(\mathrm{mg} \mathrm{dm}{ }^{3}\right)$ & 43.20 & 123.84 & 54.72 & 0.917 \\
\hline Colour intensity & 6.69 & 5.72 & 0.616 & 265.13 \\
\hline Colour tint & 0.521 & 0.923 & 350.00 & 1093.13 \\
\hline Anthocyanins $\left(\mathrm{mg} \mathrm{dm}^{3}\right)$ & 290.50 & 269.50 & 1490.00 & 31.45 \\
\hline Total phenols $\left(\mathrm{mg} \mathrm{dm}^{3}\right)$ & 1470.00 & 1181.25 & 30.79 & 54.69 \\
\hline$\%$ of the yellow colour & 30.19 & 32.35 & 57.84 & 13.86 \\
\hline$\%$ of the red colour & 57.40 & 55.06 & 11.37 & 81.50 \\
\hline$\%$ of the blue colour & 12.40 & 12.59 & 79.80 & \\
\hline Tasting evaluation & 75.70 & 76.40 & & \\
\hline
\end{tabular}


2. The 'Tempranillo' cultivar was distinguished by its considerable fertility in both microregions, but the quality of wines was lower. They had less extract and a poorer fruit aroma. The 'Syrah 99' clone from Brestnik and 'Syrah 100' clone grown in Pesnopoy did not differ significantly in productivity, but the 'Syrah 100 ' wines had a better colour intensity and the aroma was powerful, full-bodied and lasting, with dominating floral (violet) and forest fruit nuances as compared to the 'Syrah 99'.

3. Tasting scores were high, which shows the potential of the young wines, as their material and components possess the qualities necessary to develop further into top quality red wines.

\section{REFERENCES}

Babrikov D., Braikov D., Pandeliev S., 2000. Viticulture with Ampelography. Publishing House "Videnov \& Son".

Boidron R., Boursiqnot B.J., DoAzan J., Zeclair P., Zegnau M., Walter B., 1995. Catalogue des variéteś, et clones de vigne cultivés en France. CTPS, France.

BRANAS J., 1978. Les relations entre la vigne et la système climat sol. I Symposium international sur L'écologie de la vigne. Constanta.

Crespy A., 1992. Viticulture d'aujourd'hui. Lavoisier, France.

Galet P., 1993. Précis de viticulture. Ed. Dehan, Montpellier, France.

KantareV I., 1973. Guide for practical exercises in winemaking. Publishers "Hr. G. Danov", Plovdiv.

Katerov K., Peykov V., Ivanov M., 2005. Practical viticulture with ampelography. Publishers "Dionysius", Sofia.

Penkov M., 2005. Choosing the most suitable lands for establishing new vineyards and fruit orchards in Bulgaria. University Press UASG, Sofia.
Reynier A., 2001. Manuel de viticulture. Lavoisier, France.

Tomov T., Rachovski G., Kostadinova S., Manolov I., 1999. Manual in Agrochemistry. Academic Publishing House of the Agricultural University, Plovdiv.

Totev T., Gribachev P., Nechev H., Artinova M., 1999. Manual for seminars in soil science. Zemizdat, Sofia.

BADANIE JAKOŚCI WIN PRODUKOWANYCH Z ODMIAN 'SYRAH' I 'TEMPRANILLO' UPRAWIANYCH W DWÓCH MIKROREGIONACH W POŁUDNIOWEJ BUŁGARII

Streszczenie: W latach 2006-2008 prowadzono badania porównawcze odmian 'Tempranillo', 'Syrah 99' i 'Syrah 100' uprawianych w dwóch mikroregionach w południowej Bułgarii - Brestnik i Pesnopoy. Gleby w regionie Pesnopoy mają lepsze właściwości mechaniczne i skład chemiczny, co warunkuje stosunkowo wysokie plony winogron o dobrej jakości. Odmiana 'Tempranillo' była bardzo plenna w obu mikroregionach, jednak jakość otrzymanych z niej win była niższa, w porównaniu do odmiany 'Syrah'. Były one gorsze, zarówno pod względem zawartości ekstraktu, jak i aromatu owoców. Klony 'Syrah 99' z Brestnik i 'Syrah 100' z Pesnopoy nie różniły się znacząco plonem, ale wino 'Syrah 100 ' z regionu Pesnopoy miało bardziej intensywny kolor, a jego zapach był silny, bogaty i trwały z dominującą nutą kwiatów fiołka i owoców leśnych. Wyniki degustacji wykazały, że młode wina mają potencjał i zawierają składniki i komponenty niezbędne dla dalszego postępu $\mathrm{w}$ badaniach nad poprawą jakości win czerwonych.

Received May 27, 2009; accepted October 25, 2011 